\title{
Industry Partners' feedback on the OJT performance of Bachelor of Science in Information Technology (BSIT) Students
}

\author{
Jennilyn C. Mina, $\mathrm{PhD}^{1}$, Marvin DG. Garcia, MSIT $^{2}$, Ellen Jane G. Reyes, MsIT $^{3}$
}

${ }^{1}$ On-the-Job Training Coordinator, College of Management and Business Technology, Nueva Ecija University of Science and Technology, San Isidro Campus, Nueva Ecija, Philippines

${ }^{2}$ On-the-Job Training Coordinator, College of Information and Communication Technology, Nueva Ecija University of Science and Technology-San Isidro Campus, Nueva Ecija Philippines

${ }^{3}$ Faculty Member, College of Information and Communication Technology, Nueva Ecija University of Science and Technology-San Isidro Campus, Nueva Ecija, Philippines

\begin{abstract}
This study determined the feedback of trainers/supervisors regarding the respondents' personal, interpersonal and technical understanding skills in their on-the-job training (OJT) program using descriptive research design. The respondents of the study were 156 BSIT students enrolled in the OJT Program during the 2nd Semester of A.Y. 2018-2019 at Nueva Ecija University of Science Technology, San Isidro Campus.

The findings of the study have shown that the students were excellent in numerous personal skills. Likewise, they were very good in most of their technical understanding skills which are hard skills in the field of Information Technology. Still, there were areas in which students' performance need enhancement. Due to this, the researchers proposed a plan of action as an intervention to improve the program that would later result in the improvement of the students' performance in their OJT.
\end{abstract}

Keywords- Feedback, information technology, interpersonal skills, on-the-job training, personal skills, technical understanding skills.

\section{INTRODUCTION}

One of the voluminous challenges every academic institution has to face is how their graduates would fit in the industry standards when it comes to information, skills and competencies. It is necessary that the students were able to acquire the knowledge, skills, and competencies needed to address the complex social, economic and even political issues they have to face in the real battleground (Kazis, Vargas and Hoffman, 2004).In this era, where technology plays a vital role(Navarro, 2019), technology-based education particularly courses in Computer Science and Information Technology has become one of the most indemand courses nowadays (Miro, 2019). The Nueva Ecija University of Science and Technology which is composed of several campuses offering IT courses is sensible enough to have their students prepared after graduation in combating the real corporate world so that these students would be able to get a job suited in their field. The challenge has now been assumed by the academe through its On-the-Job Training and Career Development Center (Verecio, 2014).

As part of the curriculum, students will undergo On-the-Job Training (OJT) in which they were deployed to different partner agencies in the field of IT that would provide them practical experiences (Mina and Aydinan, 2019). According to Dulnuan and Saulog (n.d.), internship or practicum is a program that provides student-learners the opportunity to enhance their formal education that isfull of concepts and theories with applied knowledge, skills and desired attitudes that would eventually lead them in gaining practical experience in recognized industries. This training is a pervasive method for augmenting student-learner's productivity and cultivating their job performance (Gupta and Bostrom 2006). It connects the gap between theory and 
practice as well as between classroom education and real industry life (Laguador, 2013).

It is also an enhancement of technical knowledge, skills and attitudes of students towards work necessary for satisfactory job performance. These programs exposed the students to work on realities that would ideally hone their skills and prepare them once they get out of the university or college (Department of Labor and Employment, 2015). It means that the OJT is a two-way process wherein both parties, the companies and the students are benefited from the program.

In the study conducted by the People Management Association of the Philippines (PMAP) in 2006 which is cited by the Department of Labor and Employment (2015), it has emphasized the importance of an effective On-the-Job Training program to ensure appropriately skilled graduates as it ensures the possibility of good performer graduates. Thus, every academic institution together with national government agencies and private institutions should work together for skill-specific tasks and mentoring of the students to achieve such objectives.

Since the Nueva Ecija University of Science and Technology (NEUST) San Isidro Campusoffers Bachelor of Science in Information Technology (BSIT) as part of its undergraduate programs, aimed to produce graduates that they believe are contributing to the growing workforce of IT professionals, there is a need foran assessment as to how responsive theirgraduates have been performing during their training. This scenario triggered the researchers to conduct this study. It aimed to determine the level of OJT performance to variously identified competencies specifically in terms of their personal, interpersonal and technical understanding skills. Furthermore, as part of the ongoing efforts in the fulfillment of the University's commitment to its stakeholders, it is important that this campus is aware of the feedback of the student-learners' trainers/supervisors to their performance during their training since the quality of internship learning heavily depends on the quality of feedback and supervision by both the company and the university (Narayanan, Olk and Fukami, 2010). At the same time, this can also serve as a foundation to further improve the program currently being implemented.

\section{METHODOLOGY}

The research design utilized in this study was descriptive. Descriptive research aims to accurately and systematically describe a population, situation or phenomenon (McCombes, 2019).

The respondents of this study who were chosen purposively (Subia, 2018) were limited to the respective trainers/supervisors from the different partner agencies of all student-learners enrolled in the OJT Program of the BSIT program during the 2ns Semester of A.Y. 2018-2019 at Nueva Ecija University of Science Technology San Isidro Campus. A total of one hundred fifty-six respondents (156) participated in the survey.

The researchers used a survey-questionnaire based on CHED CMO-No. 53 s. 2006. Included in the memorandum order are expected competencies to be acquired by the graduates from BSCS, BSIT and BSIS programs. The questionnaire is divided into three parts. The first part is composed of the personal skills of the trainee, the second part is the interpersonal skills of the trainee and the last part is focused on the technical understanding skills of the trainee.

The collection of data was done through in-person distribution and the respondents were given enough time to think about their answers to the questions. Responses from the questionnaire were tabulated, analyzed and computed using frequency count, percentage and weighted mean.

Each response to every item was evaluated based on the following scale and verbal interpretation:

\begin{tabular}{|c|c|c|}
\hline Scale of Values & Limits of Scale & $\begin{array}{c}\text { Verbal } \\
\text { Interpretation }\end{array}$ \\
\hline 5.00 & $4.21-5.00$ & Excellent \\
\hline 4.00 & $3.41-4.20$ & Very Good \\
\hline 3.00 & $2.61-3.40$ & Good \\
\hline 2.00 & $1.81-2.60$ & Fair \\
\hline 1.00 & $1.00-1.80$ & Poor \\
\hline
\end{tabular}

\section{RESULTS AND DISCUSSION}

This section provides the presentation of the results of the study. Corresponding analysis and interpretation regarding some presented data were discussed. 
Table 1. Personal Skills of the Student-Trainees

\begin{tabular}{|c|l|c|c|}
\hline \multirow{2}{*}{ No. } & \multirow{2}{*}{ Indicators } & \multicolumn{2}{|c|}{ Score } \\
\cline { 3 - 4 } & & $\begin{array}{c}\text { Weighted } \\
\text { Mean }\end{array}$ & $\begin{array}{c}\text { Verbal } \\
\text { Interpretation }\end{array}$ \\
\hline 1 & Personal-discipline & 4.39 & Excellent \\
\hline 2 & Critical thinking & 4.16 & Very Good \\
\hline 3 & $\begin{array}{l}\text { Inter and Intra } \\
\text { person motivation }\end{array}$ & 4.20 & Very Good \\
\hline 4 & Problem-solving & 4.22 & Excellent \\
\hline 5 & $\begin{array}{l}\text { Planning and } \\
\text { organizing }\end{array}$ & 4.27 & Excellent \\
\hline 6 & Ethical thinking & 4.22 & Excellent \\
\hline 7 & $\begin{array}{l}\text { Entrepreneurial } \\
\text { thinking }\end{array}$ & 4.08 & Very Good \\
\hline 8 & Innovative & 4.29 & Excellent \\
\hline 9 & $\begin{array}{l}\text { Perseverance in } \\
\text { pursuing goals and } \\
\text { continuous } \\
\text { improvement }\end{array}$ & 4.43 & Excellent \\
\hline Overall Weighted Mean & $\mathbf{4 . 2 5}$ & Excellent \\
\hline
\end{tabular}

The data above displayed the feedback of the trainers/supervisors on the personal skills of the studentlearners who have undergone their training in their companies. The students were excellent in the following: perseverance in pursuing goals and continuous improvement $(\mathrm{WM}=4.43)$; innovative skills $(\mathrm{WM}=4.29)$; planning and organizing skills $(\mathrm{WM}=4.27)$ and problemsolving skills ( $\mathrm{WM}=4.22)$. It seems that the respondents were ready in the real world of work because of their higher level of personal skills particularly, problem-solving skills. Problem-solving is the most important aspect of learning which means that the respondents were capable of solving a wide variety of complex and meaningful problems as they grow older (Salangsang \& Subia, 2020; Subia, 2020).The inclination of the trainers/supervisors as they see their trainees wanting to pursue long-term goals with perseverance and passion may be determined in part by their beliefs about one's capabilities and the relative influence of external causes (Duckworth, Peterson, Matthews and Kelly, 2007). This indicator is somehow impressive on the part of the company as they see that their trainees are goal-oriented and are seeking professional development.
The trainers/supervisors, on the other hand, found the students very good in terms of their entrepreneurial thinking skillswith a weighted mean of 4.08 . Since the students are taking an IT course, they did not excel in this kind of soft skills. In this case, the educational system has to train young people who want to learn entrepreneurial skills and this can be integrated with the curriculum because ICT business needs new entrepreneurs and innovative business cultures (Juvonen and Ovaska, 2012). Interpersonal relations and even teamwork are interactive skills that are an aggregation of these aforementioned personal skills which by all means can be developed in customary programs the university has prepared for the students but a more substantial amount of the skills can only be established and acquired in the real environment of the workplace (Sabag, Trotskovsky and Schechner, 2006). According to Carter (1998), the internship is viewed as a vehicle that supports the adaptation of academic preparedness to skills required by the work market.

Table 2. Interpersonal Skills of the Student-Trainees

\begin{tabular}{|c|l|c|c|}
\hline \multirow{2}{*}{ No. } & \multicolumn{1}{|c|}{ Indicators } & \multicolumn{2}{|c|}{ Score } \\
\cline { 3 - 4 } & $\begin{array}{c}\text { Weighted } \\
\text { Mean }\end{array}$ & $\begin{array}{c}\text { Verbal } \\
\text { Interpretation }\end{array}$ \\
\hline 1 & $\begin{array}{l}\text { Teamwork } \\
\text { collaborative }\end{array}$ & 4.09 & Very Good \\
\hline 2 & $\begin{array}{l}\text { Oral and written } \\
\text { communications }\end{array}$ & 4.21 & Excellent \\
\hline 3 & Conflict resolution & 4.20 & Very Good \\
\hline \multicolumn{2}{|c|}{ Overall Weighted Mean } & $\mathbf{4 . 1 7}$ & Very Good \\
\hline
\end{tabular}

The data above exhibited the feedback of the trainers/supervisors on the interpersonal skills of the studentlearners who have undergone their OJT in their companies. It can be renowned from the data above that the students have been rated excellent by their trainers/supervisors in terms of oral and written communication skills with a weighted mean of 4.21. Communication skills, both in oral and written, are substantial for a student's academic success and future career prospects (Lucanus, 2017).On the other hand, the students were rated very good in terms of their teamwork collaborative skills with a weighted mean of 4.09. Students have been observed lacking the necessary teamwork collaborative skills (Carnegie Mellon University, 2019) that's why group projects are not working well even during 
their academics because students tend to weigh and compare their contribution to their group mates'. In the same article, it has been mentioned that real-world stories about what can go erroneous when these skills are weak can further emphasize the message that these skills are dominant to professional success. According to Phillpott (2019), on a scale of 1 to 5, managers rated the importance of having good interpersonal skills at 4.37 , just below the "ability to work in teams" (which obviously comes in at 4.49). Therefore, interpersonal skills are crucial and must be given full attention by the academicians.

Table 3. Technical Understanding Skills of the StudentTrainees

\begin{tabular}{|c|l|c|c|}
\hline \multirow{2}{*}{ No. } & \multicolumn{1}{|c|}{ Indicators } & $\begin{array}{c}|c| \\
\text { Weighted } \\
\text { Mean }\end{array}$ & $\begin{array}{c}\text { Verbal } \\
\text { Interpretation }\end{array}$ \\
\hline 1 & $\begin{array}{l}\text { System Analysis } \\
\text { and Design }\end{array}$ & 4.21 & Excellent \\
\hline 2 & $\begin{array}{l}\text { Operation of } \\
\text { Database, Network } \\
\text { and Multimedia } \\
\text { System }\end{array}$ & 4.20 & Very Good \\
\hline 3 & $\begin{array}{l}\text { Software } \\
\text { integration, testing }\end{array}$ & 4.21 & Excellent \\
\hline
\end{tabular}

\begin{tabular}{|c|l|c|c|}
\hline & and documentation & 4.14 & Very Good \\
\hline 4 & $\begin{array}{l}\text { Systems } \\
\text { management and } \\
\text { administration }\end{array}$ & 3.97 & Very Good \\
\hline 5 & $\begin{array}{l}\text { Principles of } \\
\text { Accounting }\end{array}$ & $\mathbf{4 . 1 5}$ & Very Good \\
\hline
\end{tabular}

The data above revealed the feedback of the trainers/supervisors on the technical understanding skills of the student-learners who have undergone their training in their companies. It can be remarked from the data above that the students have been rated excellent by their trainers/supervisors in terms of system analysis and design and software integration, testing and documentation with a weighted mean of 4.21 . On the other side of the coin, the student-learners were rated very good in terms of their knowledge in the principles of accounting with a weighted mean of 3.97.Information Technology (IT) may be the most stimulating program in terms of skill gaps for the reason that there is the fast speed of change in terms of hardware and software development (Patacsil and Tablatin, 2017). Yet, if the trainees have these technical understanding skills, these are entry-level skills that if they possess can provide them long-term careers (Pritchard, 2013).

Table 4. Proposed Plan of Action to Improve the OJT

\begin{tabular}{|c|c|c|c|}
\hline Problems & Reason & Strategy & Responsible Person/s \\
\hline $\begin{array}{l}\text { Oral and written } \\
\text { communications }\end{array}$ & $\begin{array}{l}\text { OJT does not express } \\
\text { well in the English } \\
\text { language but they } \\
\text { express themselves } \\
\text { more in using their } \\
\text { native language. }\end{array}$ & $\begin{array}{l}\text { Exposure to different activities involving } \\
\text { the use of the English language. } \\
\text { Creating an English zone area for students } \\
\text { and faculty to practice the use of English } \\
\text { in communication }\end{array}$ & $\begin{array}{l}\text { Students, Faculty, } \\
\text { Members of the } \\
\text { Administration }\end{array}$ \\
\hline $\begin{array}{l}\text { Operation of databases, } \\
\text { network and } \\
\text { multimedia systems }\end{array}$ & $\begin{array}{l}\text { Improper placement of } \\
\text { OJT to the company. } \\
\text { The task being assigned } \\
\text { to the OJT was more on } \\
\text { clerical works. }\end{array}$ & $\begin{array}{l}\text { - Assign to IT-based companies specifically } \\
\text { outside the province since there are a } \\
\text { limited number of IT companies present in } \\
\text { the province. } \\
\text { - To further improve the IT core functions, } \\
\text { attendance to IT seminars and conferences } \\
\text { for the latest innovation in the IT field. }\end{array}$ & $\begin{array}{l}\text { OJT Director, OJT } \\
\text { Coordinators, Students, } \\
\text { Faculty, Members of the } \\
\text { Administration }\end{array}$ \\
\hline oftware integration, & & & \\
\hline
\end{tabular}


testing and

documentation

\section{Systems management \\ and administration}

\section{Principles of accounting}

The table above presents the proposed plan of action that the researchers believe can improve the OJT program of the BSIT courses in NEUST San Isidro Campus.

\section{CONCLUSION AND RECOMMENDATION}

Based on the findings of the study, the current program of the On-the-Job Training and Career Development Center of NEUST as stipulated in its manual is operative. Although, there were areas needing improvement in terms of the three skills analyzed above. In relation to these foregoing results, the researchers formulated a proposed plan of action to strengthen and further improve the OJT program. The researchers based this proposal on some of the inadequacies found in the performance of the student-learners based on the feedback of the trainers/supervisors of the different partner agencies of the university. It is suggested by the researchers that IT educators should check and observe the trends in the world of IT to update their modules and learning materials so as to further enhance their teaching approach which would result in the enrichment of the technical understanding skills of the students. In order to sustain the delivery of quality education, the mentors in the IT Department must set a retention policy in their program and give directions to those students who could not really adapt the curriculum set by the university which is a major solution to avoid mismatch of skills. Also, the OJT Coordinators must ensure that the students were deployed to companies that are engaged in the field of IT in order for the students to gain additional learning in the real corporate world. Lastly, the university should strengthen the OJT Office wherein its function is intensive monitoring of all the interns across programs and identify qualified coordinators.

\section{REFERENCES}

[1] Carnegie Mellon University (2019). Eberly Center Teaching Excellence \& Educational Innovation Retrieved on March 30, 2020 from: https://www.cmu.edu/teaching/solveproblem/stratgroupwork/groupwork-04.html
[2] Carter, K. J. (1998). College Community Internship Program: Collaborative Efforts to Develop Local Opportunities. Journal of Career Development, 25(2)

[3] Department of Labor and Employment (2015). On-the-Job Training Manual. Retrieved on November 22, 2019 from: http://ro6.dole.gov.ph/fndr/mis/files/OJT\%20Manual\%20Upd ated\%20June\%201,\%202015.pdf

[4] Duckworth, A. L., Peterson, C., Matthews, M. D., \& Kelly, D. R. (2007). Grit: Perseverance and Passion for Long-term Goals. Journal of Personality and Social Psychology, 92(6), 1087-1101. https://doi.org/10.1037/0022-3514.92.6.1087

[5] Dulnuan, L. and Saulog, J. (n.d.). Performance of Supervised Industrial Training Students for SY 2015-2016: Basis for Program Development

[6] Gupta, S., and R.P. Bostrom. (2006). End-User Training Methods: What We Know, Need to Know, ACM.

[7] Juvonen, P. and Ovaska, P. (2012). ICT Entrepreneurship Model: A New Approach for Information Technology Bachelor Education. 14th IFAC Workshop on International Stability and Systems Engineering, Volume 45, Issue 10, 2012, Pages 50-55

[8] Kazis, R., Vargas, J. and Hoffman, N. (2004). Double the Numbers: Increasing Postsecondary Credentials for Underrepresented Youth. Harvard Education Press. ISBN-1891792-22-9

[9] Laguador, J.M. (2013). Engineering Students' Academic and on-the-Job Training Performance Appraisal Analysis. International Journal of e-education, e-Business, eManagement and e-Learning, Vol. 3, No. 4.

[10] Lucanus, Anton (2017). Oral Communication Skills Are Important for Students. Retrieved on March 27, 2020 from: https://collegepuzzle.stanford.edu/oral-communicationskills-are-important-for-students/

[11] McCombes, (2019). Descriptive Research. Retrieved on January 23, 2020 from: https://www.scribbr.com/methodology/descriptive-research/

[12] Mina, J., \& Aydinan, J. J. (2019). Trainers' Feedback on the Performance of Bachelor of Science in Criminology during their On-The-Job Training in the Tri-Bureau in the Province 
of Nueva Ecija. International Journal of English Literature and Social Sciences (IJELS), 4 (4).

[13] Miro, Aurora C. (2019). Graduate Tracer Study of University of Cebu Lapu-Lapu and Mandaue College of Computer Studies From 2011-2019, Cebu Journal of Computer Studies Vol. 2 No. 1 Page 51

[14] Narayanan, V. K., Olk, P. M., \& Fukami, C. V. (2010). Determinants of Internship Effectiveness: An Exploratory Model. Academy of Management Learning and Education, 9(1), 61-80.

[15] Navarro, Emmanuel C. (2019). Human Resource Information Management System. International Journal of Science and Research (IJSR) ISSN: 2319-7064 Volume 8 Issue 6

[16] Patacsil, Frederick F.; Lourrine S. Tablatin, Christine (2017). Exploring the Importance of Soft and Hard Skills as perceived by IT Internship Students and Industry: A Gap Analysis. Journal of Technology and Science Education, Vol. 7, No. 3, pp. 347-368

[17] Phillpott, Siôn (2019). The Importance of Interpersonal Skills in the Workplace Retrieved on March 27, 2020 from: https://www.careeraddict.com/the-importance-ofinterpersonal-skills-in-the-workplace

[18] Pritchard, J. (2013). The importance of soft skills in entrylevel employment and postsecondary success: Perspectives from employers and community colleges. Seattle, WA: Seattle Jobs Initiative.

[19] Sabag, N., Trotskovsky, E. and Schechner, P. (2006). Internship as an Obligatory Requirement for the Degree of B.Sc. in Electronic and Electrical Engineering. Proceedings of ITRE 4th International Conference on Information Technologies, Tel-Aviv, Israel, pp. 500-504.

[20] Salangsang, L. \& Subia, G.(2020). Mathematical thinking on problem solving and self-regulation strategies of Filipino primary grade pupils. International Journal of Scientific \& Technology Research, Vol.9, Issue 2.

[21] Subia, G.(2020). Fortuitous: A proposed activity-based book in mathematics of chance.International Journal of Scientific \& Technology Research, Vol.9, Issue 3.

[22] Subia, G. (2018) Comprehensible Technique in Solving Consecutive Number Problems in Algebra. Journal of Applied Mathematics and Physics, 6, 447-457. doi: 10.4236/jamp.2018.63041.

[23] Verecio, Rommel L. (2014). On-the-Job Training of the BS Information Technology Program of Leyte Normal University, Tacloban City: An Assessment. International Journal of Education and Research, Vol. 2 No. 3 